\title{
Comparative study of Conplast SP 430 and Polycarboxylic Ether based super plasticizer on M50 grade PVA-FRC
}

\author{
G.Prashanth Naik ${ }^{1}$, Srikanth Koniki ${ }^{2}$ and Hemalatha ${ }^{3}$ \\ ${ }^{1}$ M. Tech Scholar, Gokaraju Rangaraju Institute of Engineering and Technology, Hyderabad, India \\ ${ }^{2}$ Associate Professor, Gokaraju Rangaraju Institute of Engineering and Technology, Hyderabad, India \\ ${ }^{3}$ Assistant Professor, Gokaraju Rangaraju Institute of Engineering and Technology, Hyderabad, India
}

\begin{abstract}
The properties of conventional concrete is improved by addition of fiber in it. By addition of these fibers ductility of concrete is enhanced and brittleness of concrete reduced. In this study Polyvinyl alcohol (PVA) fibers are used as a reinforcing material. Polyvinyl alcohol is a high resistance nonreactive material. It will not oxidize when exposed to aggressive whether conditions and having good affinity with cement. Polyvinyl alcohol fibre of size $6 \mathrm{~mm}$ added in five proportions of $0 \%, 0.125 \%, 0.25 \%, 0.375 \%$ and $0.5 \%$. the workability of concrete decreased by addition of PVA fibers in it. So, the superplasticizers are used to improve the workability. In this study two different plasticizers Conplast SP 430 and Polycarboxylic Ether (PCE) are used and their performance on the workability and strength of concrete was worked out. The main reason for conducting this study is to find out the optimum dosage of PVA fibers, optimum dosage of super plasticizer and suggest which super plasticizer is more suitable for preparation of Polyvinyl alcohol fiber reinforced concrete.
\end{abstract}

\section{Introduction}

Contribution of concrete increases popularly in construction industry, because of its flexibility in casting, good compressive strength and resisting to weathering. The only thing that makes concrete weak is low tensile strength and brittle nature. Addition of fibers to the concrete can enhance its mechanical properties like tensile strength, ductility, toughness and abrasion Polyvinyl Alcohol (PVA) fiber are nonmetallic fiber which has advantages of where nonmagnetic and electrical insulating constructions are required. PVA fibers has good resistance to chemical and weathering, they has good affinity with cement and water and there is no health issue when they used. When PVA fibers added to the concrete it converts the mix as a ductile composite material. PVA fiber reinforced concrete (PVA-FRC) can have the advantages at the joint positions and at the positions of negative bending moments of the continuous beam. PVA-FRC can reduce the amount of reinforcing rebars and there by reduces the cost of project and difficulties in constructions. PVA fibers act as a secondary reinforcement in concrete and control the crack propagation. They can restrict the crack propagation by bridging the cracks and transfer the stresses across the crack, thereby they can improve the tensile strength of concrete. PVA fiber can control the crack propagation but allow multiple cracking under the applied load in concrete there by increases the ductility of the concrete PVA fibers can also control the plastic shrinkage and drying shrinkage in concrete. By addition of PVA fibers the workability parameters decrease in concrete. Workability of concrete dropped to down as PVA fiber fraction increases in the concrete mix. So, the use of super plasticizer necessary for the preparation of good workable PVA-FRC. The effect of super plasticizer on workability and strength parameter of the PVA-FRC were studied in this project by using two different super plasticizers of Conplast SP 430 and Carboxylic Ether (PCE) based super plasticizer.

(Zhihong Zhng et al.1995) Advantages of PVA fibers are the have high tensile strength, good affinity with cement and water, it will not cause any health issues if used. Because of non-circular cross section of PVA fibers and hydrogen bond between the PVA fibers and cement they build good inter-facial bond with concrete matrix and develop good flexural strength of concrete beams.

In this study, the work is performed on the workability of concrete by slump cone test, compressive strength and split tensile strength of PVA fiber reinforced concrete by using two different plasticizers of Conplast SP430 and Carboxylic Ether based super plasticizer. Comparing the obtained result by using two plasticizer and finding out which is the most suitable for the PVA fiber reinforced concrete.

\section{Objectives}

The main aim of this investigation is finding out the Workability, Compressive strength of cube and Split tensile strength of cylinders for M50 grade PVA fiber 
reinforced concrete for various proportion of PVA fiber using two different super plasticizer and comparing the results with conventional concrete.

\section{Collection of Materials}

\subsection{Cement}

Ordinary Portland cement (OPC) of grade 53 is used in concrete for the casting of cubes and cylinder and the specific gravity of cement is 3.15 .

\subsection{Fine Aggregate}

Locally available Natural river sand which is free from pebbles and organic matter is used in concrete as the fine aggregate for the casting of cubes and cylinder. The specific gravity of sand was found to be 2.6.

\subsection{Coarse Aggregate}

Angular shaped Broken stones of hard granite of size 20 $\mathrm{mm}$ and $10 \mathrm{~mm}$ were used in concrete as coarse aggregate. The specific gravity of coarse aggregate was found to be 2.62 .

\subsection{PVA Fibre}

Polyvinyl alcohol of size $6 \mathrm{~mm}$ was used in this project. Specific gravity of fibers is 1.29 .

\subsection{Polycarboxylic ether (PCE) super plasticizer}

Polycarboxylic ether become one of the most important effective super plasticizer because of their superior performance. It work differently from sulfonated based super plasticizer. It gives the cement dispersion by steric stabilization instead of electrostatic repulsion. It has the ability to fluidize the mix even at low water cement ratio.

\subsection{Conplast super plasticizer}

Conplast SP 430 super plasticizer is a chloride free admixure based on sulfonated napthalene polymers, which instantly disperses the water in the concrete mix. It quickly makes the mix fluidity at small amount of addition.
Table 1. Properties of PVA fibers

\begin{tabular}{|l|l|}
\hline Material & $100 \%$ PVA \\
\hline Specific gravity & 1.29 \\
\hline Formula & $\left(\mathrm{CH}_{2} \mathrm{CHOH}\right) \mathrm{n}$ \\
\hline Fibre type & Bunchy monofilaments \\
\hline Length & $6 \mathrm{~mm}$ \\
\hline
\end{tabular}

Table 2. Material Properties

\begin{tabular}{|l|l|l|}
\hline S.No & Test & Result \\
\hline 1 & Test on cement & \\
\hline 2 & Specific gravity & 3.15 \\
\hline 3 & $\begin{array}{l}\text { Normal } \\
\text { consistency }\end{array}$ & $31 \%$ \\
\hline 4 & Initial setting time & $35 \mathrm{~min}$ \\
\hline & Fineness Test & $7.5 \%$ \\
\hline 5 & $\begin{array}{l}\text { Test on fine } \\
\text { Aggregate }\end{array}$ & 2.6 \\
\hline 6 & Specific gravity & $\begin{array}{l}\text { Test on coarse } \\
\text { Aggregate }\end{array}$ \\
\hline & Specific gravity & 2.62 \\
\hline
\end{tabular}

\section{Mix Design}

Concrete mix design is prepared for M50 grade of concrete as per IS 10262-2019

Table 3. Concrete mix design

\begin{tabular}{|l|l|l|l|l|l|}
\hline Material & Cement & $\begin{array}{l}\text { Fly } \\
\text { ash }\end{array}$ & $\begin{array}{l}\text { Fine } \\
\text { aggregate }\end{array}$ & $\begin{array}{l}\text { Coarse } \\
\text { aggregate }\end{array}$ & Water \\
\hline $\begin{array}{l}\text { Weight }(\mathrm{kg} \\
\left.\text { per } \mathrm{m}^{3}\right)\end{array}$ & 430 & 100 & 670 & 1004 & 196 \\
\hline Proportions & 1 & 0.23 & 1.56 & 2.34 & 0.45 \\
\hline
\end{tabular}

The above proportions is made for the M50 grade of concrete and cement of grade OPC 53 is used. Coarse aggregates in two different size of $20 \mathrm{~mm}$ and $10 \mathrm{~mm}$ are used in equal proportion. Design mix is done for the slump value of $50-100$. The mix design is prepared for the target mean strength of $58.25 \mathrm{~N} / \mathrm{mm}^{2}$ which is obtained as per IS 10262-2019. Based on this target strength water cement ratio is obtained from table 5 of IS 456 for respective exposer condition. Then required amount of water content, cement, coarse aggregate and fine aggregate are calculated by using IS 10262-2019. 


\section{Details of casting}

\subsection{Preparation of mould}

The moulds are used for the casting of cubes and cylinders. Which were made up of cast iron and has smooth inner surface. The mould is assembled and fixed by nuts and bolts. Base plate also fixed to the mould by using nuts and bolts. Inner surface of the moulds must coated with mould oil to avoid sticking of the concrete on the surface of the mould and for the easy removal of sample from the mould after hardening.

Table 4. Details of mould specification

\begin{tabular}{|l|l|}
\hline Type of mould & Size (in mm) \\
\hline Cube & $150^{*} 150$ \\
\hline Cylinder & $150 * 300$ \\
\hline
\end{tabular}

\subsection{Mixing}

Uniform mixing of all materials in concrete is essential for the production of good homogeneous concrete. So we adopted machine mixing for preparation of uniform concrete. Fibre must be added in the concrete before addition of water and mix the sample five minutes for uniform mixing and to avoid the agglomeration. While mixing super plasticizer must be added in mixed with water.

\subsection{Slump test}

Slump cone test is used to measure the consistency of freshly prepared concrete and also indicate the workability of concrete to do the ease of work. After mixing concrete pour the concrete mix in slump cone and fill the cone by three layers. Each layer each layer having one third of height and tampered with tamping rod by 24 blows. Remove the slump cone and measure the decrease in height of concrete.

\subsection{Compaction}

In the process of compaction entrapped air in concrete is expelled out. Air is entrapped in concrete while in the process of mixing, transporting and placing. Due to this concrete become porous and the strength of concrete is reduced. In this project we adopted table vibrator for the compaction of concrete in moulds and cylinders.

\subsection{Curing}

After compaction place the moulds at a place at room temperature for hardening of concrete for 24 hours. Remove the concrete samples from the mould after 24 hours of casting. After removal of sample place it in ordinary curing tank for the period of 28 days.

\section{Test results and discussions}

\subsection{Amount of super plasticizer added}

In the below table 5. it shows that amount of plasticizer added to the concrete to get the workable concrete of slump value is in between $50-100 \mathrm{~mm}$.

From the above observation, Conplast SP 430 super plasticizer gives quick workability for preparation of PVA fiber reinforced concrete at small amount of addition as compared with the polycarboxylic Ether (PCE) based super plasticizer.

Table 5. Amount of super plasticizer added and respective slump value

\begin{tabular}{|l|l|l|l|l|}
\hline $\begin{array}{l}\text { S.N } \\
\text { o }\end{array}$ & $\begin{array}{l}\text { PVA } \\
\text { Fibers }\end{array}$ & $\begin{array}{l}\text { Conplast } \\
\text { SP 430 }\end{array}$ & $\begin{array}{l}\text { Polycarboxylic } \\
\text { Ether (PCE) }\end{array}$ & $\begin{array}{l}\text { Slump } \\
(\mathbf{m m})\end{array}$ \\
\hline 1 & $0 \%$ & $0.3 \%$ & - & 90 \\
\hline 2 & $0.125 \%$ & $0.6 \%$ & - & 80 \\
\hline 3 & $0.25 \%$ & $0.8 \%$ & - & 75 \\
\hline 4 & $0.375 \%$ & $1.5 \%$ & - & 70 \\
\hline 5 & $0.5 \%$ & $2 \%$ & - & 65 \\
\hline 6 & $0 \%$ & - & $1 \%$ & 85 \\
\hline 7 & $0.125 \%$ & - & $1.2 \%$ & 72 \\
\hline 8 & $0.25 \%$ & - & $1.6 \%$ & 69 \\
\hline 9 & $0.375 \%$ & - & $2 \%$ & 65 \\
\hline 10 & $0.5 \%$ & - & $2.2 \%$ & 63 \\
\hline
\end{tabular}

\subsection{Compressive strength test}

Table 6. Compressive Strength of concrete at 28 days using plasticizer conplast SP 430

\begin{tabular}{|l|l|l|l|}
\hline Sample & PVA Fiber & $\begin{array}{l}\text { Compressive } \\
\text { strength } \\
\text { (MPa) }\end{array}$ & \% change \\
\hline 1 & $0 \%$ & 57.5 & - \\
\hline 2 & $0.125 \%$ & 59.2 & $+2.95 \%$ \\
\hline 3 & $0.25 \%$ & 61.4 & $+6.78 \%$ \\
\hline 4 & $0.375 \%$ & 60.3 & $4.86 \%$ \\
\hline 5 & $0.5 \%$ & 55 & $-4.34 \%$ \\
\hline
\end{tabular}

Table 7. Compressive Strength of concrete at 28 days using plasticizer polycarboxylic ether (PCE)

\begin{tabular}{|l|l|l|l|}
\hline Sample & PVA Fiber & $\begin{array}{l}\text { Compressive } \\
\text { strength (MPa) }\end{array}$ & \% change \\
\hline 1 & $0 \%$ & 57.5 & \\
\hline 2 & $0.125 \%$ & 60 & +4.34 \\
\hline 3 & $0.25 \%$ & 63.2 & +9.91 \\
\hline 4 & $0.375 \%$ & 65 & +13 \\
\hline 5 & $0.5 \%$ & 64 & +11.3 \\
\hline
\end{tabular}

Comparison of Compressive strength variation of concrete using conplast SP 430 and PCE. 


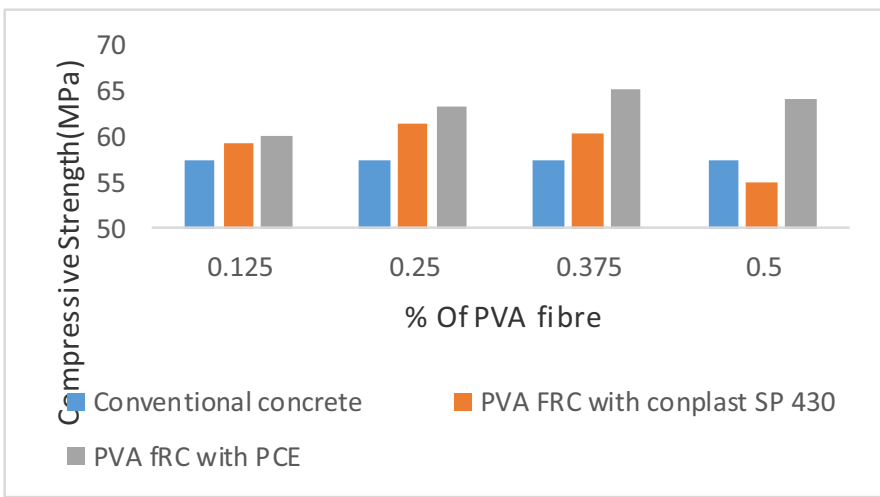

Fig. 1. variation of compressive strength

The compressive strength of PVA fiber reinforced concrete initially increases with increasing the volume of fiber content. Because of more amount fiber content agglomeration of fibers and improper compaction of concrete takes places. The strength value decreases with adding more amount of PVA fibers.

PVA fiber reinforced concrete with Polycarboxylic ether based super plasticizer develop 13\% more compressive strength at $0.375 \%$ of PVA fiber content.

PVA fiber reinforced concrete with super plasticizer conplast SP 430 develop $6.78 \%$ more compressive strength at $0.25 \%$ of PVA fiber content.

\subsection{Split tensile strength test}

Table 8. Split tensile Strength of concrete at 28 days using plasticizer conplast SP 430

\begin{tabular}{|l|l|l|l|}
\hline Sample & PVA Fiber & $\begin{array}{l}\text { Split tensile } \\
\text { strength } \\
\text { (MPa) }\end{array}$ & \% Change \\
\hline 1 & $0 \%$ & 4.025 & - \\
\hline 2 & $0.125 \%$ & 4.23 & +5.09 \\
\hline 3 & $0.25 \%$ & 4.54 & +12.79 \\
\hline 4 & $0.375 \%$ & 4.31 & +7.08 \\
\hline 5 & $0.5 \%$ & 3.9 & -3.1 \\
\hline
\end{tabular}

Table 9. Split tensile Strength of concrete at 28 days using plasticizer polycarboxylic ether (PCE)

\begin{tabular}{|l|l|l|l|}
\hline Sample & PVA Fiber & $\begin{array}{l}\text { Split tensile } \\
\text { strength } \\
\text { (MPa) }\end{array}$ & \% Change \\
\hline 1 & $0 \%$ & 4.025 & - \\
\hline 2 & $0.125 \%$ & 4.77 & +18.5 \\
\hline 3 & $0.25 \%$ & 4.89 & +21.49 \\
\hline 4 & $0.375 \%$ & 4.29 & +6.58 \\
\hline 5 & $0.5 \%$ & 4.11 & +2.11 \\
\hline
\end{tabular}

Comparison of split tensile strength variation of concrete using conplast SP 430 and Polycarboxylic Ether (PCE)

Split tensile strength of concrete increases significantly with addition of PVA fibers. Because of bridging characteristics of fibers load is transfer at the cracks. With increasing the amount of more fiber content split tensile strength is decreased due to fiber agglomeration and improper compaction.

PVA fiber reinforced concrete with polycarboxylic ether develop $21.49 \%$ more strength and with conplast SP 430 develop $12.79 \%$ more strength then conventional concrete at PVA fiber content of $0.25 \%$.

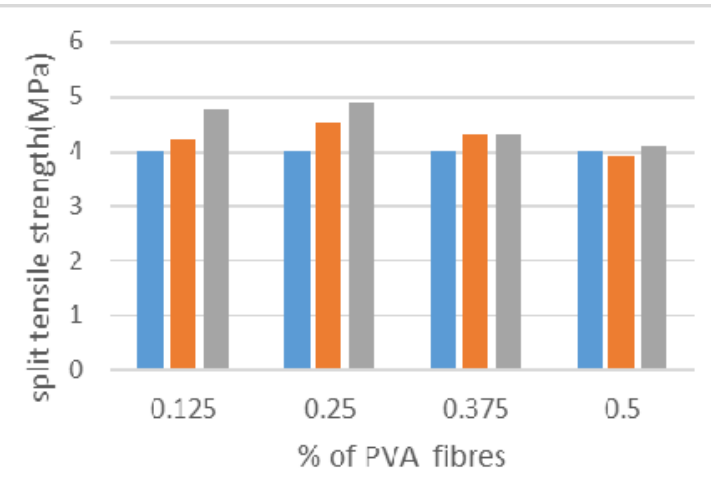

- conventional concrete $\quad$ complast sp $430 \square$ PCE

Fig. 2. variation of split tensile strength

\section{Conclusion}

Workability of Conplast SP 430 based concrete mixes are more as compared with Polycarboxylic Ether based mixes.

Strength of Polycarboxylic Ether based concrete are more as compared with Conplast SP 430.

Optimum dosage of PVA fiber content is achieved at $0.25 \%$ of volume of concrete.

Compressive strength improvement of concrete with addition of PVA fiber is $6.78 \%$ and $13 \%$ using Conplast SP 430 and Polycarboxylic Ether.

Split tensile strength improvement of concrete with addition of PVA fiber is $12.79 \%$ and $21.49 \%$ using Conplast SP 430 and Polycarboxylic Ether.

\section{References}

1. Noushini, Amin, Kirk Vessalas, and Bijan Samali. Proceedings of the Thirteenth East Asia-Pacific Conference on Structural Engineering and Construction (EASEC-13). The Thirteenth East Asia-Pacific Conference on Structural Engineering and Construction (EASEC-13), (2013) 
2. Noushini, Amin, Bijan Samali, and Kirk Vessalas. Proceedings of the 8th International Conference on Fracture Mechanics of Concrete and Concrete Structures, FraMCoS (2013)

3. Zheng, Zhihong, and Dorel Feldman. "Synthetic fibre-reinforced concrete. 185-210 (1995)

4. Noushini, Amin, Bijan Samali, and Kirk Vessalas. Construction and Building Materials 49 374-383 (2013)

5. Haskett, M., Mohamed Sadakkathulla, M., Oehlers, D., Guest, G., Pritchard, T., Sedev, V., \& Stapleton, B. (2012)

6. Koniki, Srikanth, and D. Ravi Prasad. Construction and Building Materials 207 238-248 (2019)

7. Nataraja, M. C., and Lelin Das. "Concrete mix proportioning as per IS 10262: 2009-Comparison with IS 10262: 1982 and ACI 211.1-91." The Indian Concrete Journal 64-70 (2010)

8. IS 456-2000, Concrete Mix Proportioning Guidelines, BIS, New Delhi, India, (2000)

9. IS 10262-2000, Plain and Reinforced Concrete Code of Practice, BIS, New Delhi, India, (2000)

10. IS: 9103-1999, Standard Specification for Chemical Admixtures for Concrete, BIS, New Delhi, India, (1999)

11. IS: 383-1970 (Reaffirmed 2002), Indian Standard Specification for Coarse and Fine Aggregates from Natural Sources for Concrete, BIS, New Delhi, India, (2002)

12. IS: 12269 - 2013, Indian Standard Ordinary Portland cement, 53 Grade - Specification, BIS, New Delhi, India, (2013)

13. Redon, Carl, Victor C. Li, Cynthia Wu, Hideki Hoshiro, Tadashi Saito, and Atsuhisa Ogawa. Journal of materials in civil engineering 13, no. 6 399-406 (2001)

14. Toutanji, Houssam A., and Mohamed Saafi. Structural Journal 97.5 712-719 (2000)

15. Benmokrane, Brahim, et al. Journal of Composites for Construction 6.3 143-153 (2002)

16. De Luca, Antonio, Fabio Matta, and Antonio Nanni. ACI structural journal 107.5589 (2010)

17. Alsayed, S. H., Y. A. Al-Salloum, and T. H. Almusallam. Composites Part B: Engineering 31.67 555-567 (2000)

18. Koniki, Srikanth, et al. Innovative Infrastructure Solutions 6.3 1-14 (2021)

19. Prathipati, SRR Teja, et al. Materials Today: Proceedings 38 2541-2548 (2021)

20. Ramesh, Vemundla, and Koniki Srikanth. E3S Web of Conferences. Vol. 184. EDP Sciences, (2020) 